\title{
The Social Group Distinction of Nationalists and Globalists amid COVID-19 Pandemic
}

\author{
Zhining $\mathrm{He}^{1} \mathbb{1} \cdot$ Zhe Chen $^{2}$
}

Received: 15 July 2020 / Accepted: 7 November 2020 / Published online: 23 November 2020

(c) Fudan University 2020

\begin{abstract}
The primary discussion in this article is the classification of the typical reactions of social groups in various nations as nationalist and globalist. Subject to the new coronavirus pandemic, nationalists have adopted extreme national security policies, namely, "the nation's interests prevails;" globalists have adopted moderate policies by complying with the faith of society in the recommendations of the scientific community. The disparate contrasts in values and actions between the two groups are extensively manifested in domestic disease control, attitude toward the World Health Organization, identification of the disease's source, vaccine research, international cooperation, and social reaction. This research indicates that nationalists largely consist of conservative country leaders, "social elites," populists, and individuals in the middle-lower class, many of whom uphold racism and extreme nationalism, and that globalists largely consist of international organizations and regional leaders, medical practitioners, intellectuals and philanthropic entrepreneurs, the middleupper class population. This social group distinction is clarified in accordance with converse ethical value perspectives, ideologies, social group-economic interests, and even national competition positions. Regarding cultural and institutional basics, nationalists uphold neoliberalism, social Darwinism, the law of jungle, and individualism, whereas globalists advocate for social democracy and collectivistic ethnic codes. The two parties have been competing for the high moral ground during and the pandemic, thereby profoundly affecting the relationships of nations worldwide.
\end{abstract}

Keywords COVID-19 $\cdot$ Nationalists $\cdot$ Globalists $\cdot$ Social group distinction

Zhining He

viktorhe@hotmail.com

Zhe Chen

z.chen83@1se.ac.uk

1 Southeast University, Nanjing, China

2 The London School of Economics and Political Science, London, UK 


\section{Introduction}

Under the global new coronavirus (COVID-19) pandemic, all countries have implemented different measures and achieved disparate response effects. The COVID-19 pandemic is a novel topic of contemporary globalization. Globalization has long indicated close communication and division of labor and cooperation between nation-states. Thus, this study will answer why different countries have implemented different measures against the same pandemic, as well as the type of social structure and international political mechanism.

The differences in attitudes and strategies of different countries and groups are attributed to the current differences between nationalists and globalists. Given the response of social groups in different nations to the COVID-19 pandemic, this study splits social groups into nationalists and globalists. By tracking the responses against a global pandemic, findings were obtained: nationalists have implemented unilateralism and anti-globalization measures, whereas globalists have implemented social democracy measures and cooperative governance countermeasures.

From the perspective of globalization, the differences between nationalists and globalists are demonstrated comparatively, and then the social mechanism that triggered the differences in disease management is determined. The classification of nationalists and globalists under the pandemic complies with the different values and social actions of different social groups in various countries in terms of domestic disease control, attitude toward the World Health Organization (WHO), identification of disease source, vaccine research, international cooperation, and social reaction. According to the two groups, representative figures and institutions have been developed, which, respectively, manifest the pursuit of neoliberal capitalism and social democracy separately. The two groups have significantly different values and social actions.

The analysis of the values and social actions of specific populations and institutions in two different social groups can be an argument for the comparative study on nationalists and globalists during the pandemic. As indicated from a comparative study on the values and social actions of nationalists and globalists, nationalists primarily consist of conservative country leaders, "social elites," populists, and the middle-lower classes of society, while globalists are largely leaders of international and regional organizations, scientists, professional officials and medical practitioners, philanthropic entrepreneurs, and the upper-middle class of society.

By analyzing nationalists and globalists during the pandemic, this study investigates the further impact on globalization of the tension between the two groups. It could be predicted that because of the COVID-19 pandemic, the globalization mode will be significantly altered, but globalization will still exhibit significant vitality in the contemporary era. The isolationism of extreme nationalists will not help solve the global public health crisis and might jeopardize nation-states.

Additionally, this study attempts to explore the changes in the international pattern in the new era of globalization under the world system theory. Though the 
modern world system theory of Immanuel Wallerstein primarily studies the division of labor in the world's economic system, the framework can account for the formation of nationalists and globalists and the division of social groups under the pandemic.

\section{Literature Review}

The tension between nationalism and globalism in this globalization era can, to some extent, determine the fate of the contemporary nation-state, as well as future globalization development (Greenfeld 2011). Several studies have been conducted on nationalism in the context of globalization. In some scenarios, globalization tends to cause the aggravated nationalism consciousness of certain groups. Additionally, the movement and exchange of different nationalities across national boundaries boost the growth of nationalism. Moreover, under contemporary globalization, nationalism and globalism interact (Nyíri et al. 2010). As it is affected by the common impact of globalization, nationalism and globalism interact with and even penetrate each other (Audi 2009).

In terms of domestic politics, globalization affects the domestic politics of nationstates, as well as deepens the nationalist thoughts in a country under certain conditions. Globalization tends to affect regional relations and those among different social groups. The interest gap among different regions and different social groups within a nation-state under globalization has resulted in structural tension among these regions and social groups (Ohanyan 2010). Furthermore, the structural tension between nationalists and globalists can shape the implementation of democratic politics in contemporary nation-states (Scotto et al. 2018).

For international politics, globalization blurs the boundaries of nation-states and makes the world become a community. However, this type of assimilation intensifies the sharp conflict between nationalists and globalists within the nation-state. Supporters of globalization are obsessed with the disappearance of nation-state borders, which conservative nationalists deem intolerable. In this globalization era, nationalists are committed to safeguarding their so-called cultural traditions and economic interests (Warf 2012).

This study inherits the general definitions of nationalism and globalism (Kacowicz 1999). Globalization, as well as nationalism, can be considered a type of ideology held by a particular social group. Globalism and nationalism are usually used in opposite ways (Malesevic 2002), and nationalism has a longer history of development than globalism. Some theories presume a period of "classical" nation-state before the twentieth century (Hutchinson 2003). Nationalism originates from the gradual establishment of national and state boundaries; it has been advanced to a peak under the modern nation-state, during which time the nation-state exhibits having the most authoritative sovereignty over all issues within its territory. Compared with globalism, nationalism emphasizes the sense of belonging to a country and nation for the members of communities. The interest of the whole political and kinship social group prevails over personal interests (Malesevic 2002). 
The era of globalization has affected the boundaries of the nation-state and stimulated the nationalists within the nation-state. Nationalists aim to maintain the uniqueness of the nation (Malesevic 2002). For their interests and the interests of their nation, they are opposed to globalization in different manners. They diminish the universal pursuit of human beings, whereas they emphasize the special interests of their nation (Malesevic 2002). Instead of "external," nationalists primarily focus on "internal" problems within their nations (Hutchinson 2003). Nationalists emphasize the opposition between the members and non-members of the nation (De Cleen 2017). In several cases, the in-group identification can act as a tool for the social mobilization of nationalists (Goodman 2002).

Globalization upheld by globalists is generally considered the intensification of economic, political, social, and cultural ties between contemporary nations. Nations worldwide bid farewell to the era of mutual opposition and then gradually integrated into a whole. The contemporary world is heading to the intensification of interconnections among peoples globally while transforming individuals" notion of "local" (Hutchinson 2003). Advocating individual freedom, globalism promotes progress and rationality, eliminating political borders, and the free flow of individuals and goods (Malesevic 2002).

Instead of the nation-state, regional and international communities are what globalists have a solid faith in. Moreover, progressivism arouses an objective attitude from globalists toward natural science (Malesevic 2002). Globalization has long been accompanied by the prevalence of Western values, a neoliberal economy, and Western democracy, typically manifested by the US' globalization and not dominated by a single power; it is shared by all the members in this process (Steger 2005). Because of the increase in new global threats (e.g., climate change and international terrorism), a single nation-state cannot solve the aforementioned problems individually (Hutchinson 2003). Cooperation is the way for nation-states to resolve global issues in the view of globalists.

Bourdieu (1984) presented a world of social distinctions in his classic works. His definition of social segregation complies with the so-called cultural capital, which is based on a profound social, economic stratification root. In his works, groups with different social and economic status have different cultural capitals, and the gradient difference of cultural capital is revealed by individuals' habits. Individuals classify each other as different social groups by habits, thereby causing social group distinctions. Unlike Bourdieu's concept of distinction, the basis of social group distinction in this study is pan-political, instead of simply complying with the socioeconomic status or cultural capital of social groups. In contemporary globalization, the boundary of the nation-state is gradually blurred, whereas with the development of network technology, individuals of different classes are more closely linked than separated. Through the internet, individuals access the life of different classes', and at least on the surface, the differences between classes have been blurred. Political identity has become a novel means of self-identity beyond race, class, and gender. The talks of country leaders will be spread to the internet terminals of individuals of all races and classes in a significantly short period, thereby causing cross-class political discussions. In individual' discussions on national politics, political inclination has become the main criterion of group distinction. 
The COVID-19 pandemic is a by-product of contemporary globalization, even "anti-globalization" to a certain extent. Following the flow of individuals, the virus rapidly spread worldwide. Thus, in the early stage of the pandemic, a few countries banned the entrance of citizens of other countries and, instead, attempted to prevent the spread of the virus in other manners. However, with the development of the pandemic, the virus has spread to almost every country. Internal management of the virus has become the primary concern of the nation-states, and differences between the nationalists and globalists have been observed.

In the United States, Brazil, UK, Russia, and some other countries, mostly nationalists hold the country's political and discourse power, and they are generally supported by the voters who elected them. These countries have some political, economic, and social resource advantages over other countries but have been unwilling to implement public health policies with the proper restrictions during the pandemic, as evidenced by their high death and infection rates. In countries such as China and Germany, globalists have a voice in politics; thus, scientific and objective pandemic response measures have been be effectively implemented in these countries, and these countries have contributed to the effective global pandemic response. Worldwide, medical practitioners, philanthropic entrepreneurs, and intellectuals have supported the cooperation strategy of mutualism. Different groups have differences in values and actions, leading to the social group distinctions between nationalists and globalists on a global scale (Table 1).

Using the comparative method, the significant differences between nationalists and globalists in response to the pandemic can be compared. The reasons for doing that are elucidated below. First, comparison is a conventional means of analysis. With the comparative method, the characteristics and differences of different subjects and individuals can be found, and general laws are explored. Second, this study focuses on the pandemic, for which the subject of the individuals is the same. Third, nationalists and globalists are two social ideological trends, and social subjects that have long been inconsistent with each other in values and social actions. By comparing their different values and social actions while managing the pandemic, the two disparate groups' differences can be revealed.

The study analyses different national governments, vital figures, social organizations, and social groups during the pandemic from the perspective of globalization and anti-globalization, which are hotspots in international political study. A proposal is that individuals can become nationalists and globalists. The division of social groups into nationalists and globalists is not or less correlated with class, division of labor, occupation, and culture; by contrast, it exists as a spiritual community and a social group beyond time and space, namely, based on the values beyond their individual characteristics and the common social actions induced by the latter. Accordingly, it is necessary to advance beyond the conventional method, to distinguish social stratification and social groups in sociology, and take the macroscopic perspective capable of distinguishing the generality and differences between individuals or groups, namely, their inherent values and corresponding social actions, especially for an identical problem or specific event.

The distinctions between nationalists and globalists are analyzed for values and social actions. First, values refer to the ideological perspective of dividing the 


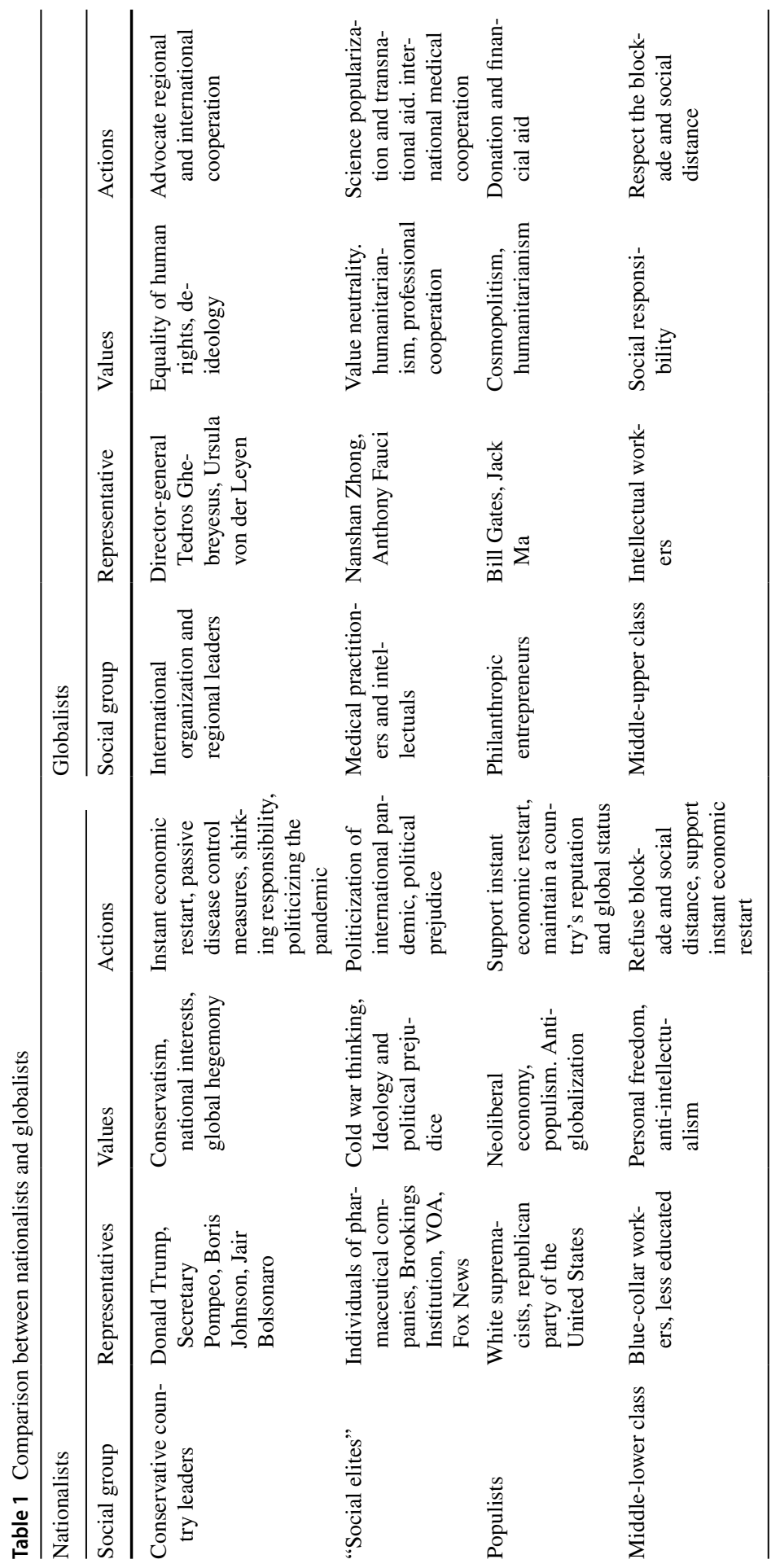


fundamental differences of different social groups, which are worldviews basically solidified in individuals' minds. Second, values are historically formed by complying with the inherent differences of social groups. These values have a long-term conventional background and cultural genes, which are difficult to change. Third, values, directly or indirectly and overtly or implicitly, affect the social actions of social groups. All these have triggered essential differences in individuals' values and actions. Thus, to analyze the differences and social isolation between nationalists and globalists during the pandemic, the essential differences in individuals' values and social actions should be known.

Accordingly, under the common threat of global disease, the two social groups, nationalists and globalists, are bound to be separated based on different values of globalization and social groups that implement different social actions, which is determined by their inherent ideology, political position, cultural concept, national consciousness, and social interests.

Based on this explanation, the following is consistent with the analytical logic, namely, to divide individuals into two opposite social groups through the unexpectedly different anti-globalization and globalization values and corresponding social actions reflected by a global and imminent common threat, which is a security event of human public health, that is, the new global pandemic.

The findings from analyzing reports and information demonstrate that the representative nationalists are primarily the heads of state, "social elites," and populist politicians. The typical globalists act as the leaders of regional organizations, scientists, medical practitioners, and philanthropic entrepreneurs. The aforementioned representative figures and groups refer to individuals and social groups distributed in different institutions, organizations, and communities in the national system. Admittedly, similarities also exist between nationalists and globalists. This study emphasizes their respective representativeness and typicality, which is the part of pure nationalists and globalists whose different social actions are consistent when subject to the pandemic.

Notably, the "state government" has been eliminated from the nationalist group because it belongs to social organizations instead of social groups, and it is replaced by some leaders of government. In this study, "media" is not analyzed as a dimension because the same media may show nationalism and globalism regarding the pandemic, and it is difficult to categorize them precisely. In addition, "scientists, former officials of professional departments," "medical staff, [and] intellectuals" who are globalists are summarized as "medical practitioners and intellectuals." Accordingly, the concrete comparison between nationalists and globalists is more concentrated, which underpins comparative analyses.

\section{Comparison Between Nationalists and Globalists}

By analyzing the attitude and measures taken by management systems and the public since the outbreak of the pandemic, different individuals in domestic disease control, attitudes toward the WHO, identification of disease source, vaccine research, and international cooperation have different values and social reactions in the six 
main aspects of response. These people's subjective initiatives in these six key aspects can optimally reflect and distinguish whether they pertain to nationalists or globalists. The aforementioned six aspects are independent of each other but have some internal logical relations.

For domestic disease control, experiencing the common natural enemy of nonpoliticization interests, nationalists and globalists have different reactions to this issue. The attitude and measures of domestic prevention and control of the global pandemic situation reflect the unique values and worldview of nationalists and populists. The attitude toward the WHO is capable of directly and significantly indicating the attitude of social groups toward the international public health organization during the global public health crisis. The WHO is the most authoritative, professional international organization in global public health security. By opposing or supporting the WHO, the social group can be typically judged as nationalists or globalists. Moreover, the difference between nationalists and globalists is highlighted in the subjective artificial operation or objective scientific judgment on the identification of the disease source. For a natural biological phenomenon, whether the origin of the virus is determined subjectively can indicate the values of social groups. Vaccine research is another area in which scientists worldwide can cooperate and is recognized as a symbol of national strength and status by nationalists. However, the attitude and behavior of globalists are nearly the opposite, namely, vaccine research and development should be transparent and shared. International cooperation is inevitable in a pandemic in a globalized society. While on this point, the values and social actions of nationalists and globalists are also quite different. Social reaction, the social response of the individuals of various countries, can also be distinguished between nationalists and globalists. It is the expression of the general opinion and will of the public which can help distinguish whether the societies of a wide range of nations have become populists or the more open after the prior globalism.

\subsection{Domestic Disease Control}

Domestic disease control has evolved into a global problem because of different attitudes and measures. The countries administrated by nationalists exaggerate their national prevention and control capabilities and effectiveness and play down the severity of the pandemic, to maintain the economy and employment; notably, these countries have the most serious pandemic situations; the countries led by globalists have preferred to temporarily slow economic development while strictly controlling the pandemic situation on the basis of scientific information.

Nationalists oppose the closure of cities and social distancing and erroneously believe in the efficacy of passive disease control measures and that an instant economic restart would be beneficial. They posit that the pandemic is not serious and will disappear quickly. From the head of state to the nationalists in the grassroots, they hold a "positive and optimistic" attitude. For instance, US President Donald Trump and Brazilian President Bolsonaro concealed and distorted disease data and then promoted instant economic restart. British Prime Minister Boris Johnson proposed that the United Kingdom would manage the coronavirus through herd 
immunity. The results of these plans have been catastrophic: the number of cases and deaths in the United States is the highest worldwide, and that in the United Kingdom is also one among the highest. Trump, Bolsonaro, and Johnson are antiglobalist nationalists at different levels and degrees and that have supposedly prioritized the world status of their countries.

On April 16, 2020, Trump proposed a three-stage plan to restart the US economy (Mason and Holland 2020) and even held campaign rallies in closed stadiums despite the spread of the coronavirus (LeBlanc 2020). As a result, as of July 15, 2020, the United States had the highest number of new cases, cumulative confirmed cases, and deaths worldwide (Johns Hopkins University 2020). More than 12 US states have suspended their economic restart. Notably, despite its negative outcomes, the White House lied and said the US was the global leader in fighting the pandemic (Braddick 2020). This language is the nationalist speech of Trump's "America first" rhetoric. By July 15, 2020, Brazil's cumulative number of cases ranked second worldwide (Johns Hopkins University 2020). British Prime Minister Johnson abandoned prevention and treatment, thus the herd immunity strategy, and promoted merely waiting for a vaccine. The cumulative number of cases and deaths in the United Kingdom was once the highest in the European Union. Russian President Vladimir Putin held a parade on June 24, despite the disease being out of control in Russia (BBC 2020a, b). The consequence is that on July 9, the total number of cases in Russia was more than 700,000 (Johns Hopkins University 2020).

By contrast, China, Germany, Japan, and South Korea have implemented firm, effective, science-based prevention and control measures after the early stage of the pandemic were recognized. The leaders and most of the individuals in the aforementioned countries have supported globalism and actively participated in international anti-disease cooperation. The number of cases and mortality rates in those countries are of the lowest levels worldwide (Johns Hopkins University 2020).

\subsection{Attitude Towards WHO}

Attitudes toward WHO are also a significant touchstone to distinguish between nationalists and globalists. The WHO is the most critical and irreplaceable international organization in the fight against the global pandemic, has been operating correctly and well, and has earned the trust and support of governments and individuals of different countries. Notably, nationalists and populists have demonstrated dissatisfaction with the WHO by denying and resisting it unilaterally.

Nationalists and globalists comply with different positioning and action strategies for international organizations such as the WHO. While managing the internal crisis, the head of government and the conservative aides of the United States consistently shirked their responsibilities to the WHO and finally left the organization (Lynch and Rauhala 2020). This global view is supposedly guided by national interests. A similar isolationist tendency in the cabinet of Brazil and other countries has been observed.

The leaders of the European Union (EU) and China, however, have supported WHO and proactively participated in international cooperation in response to the 
pandemic. Furthermore, Bill Gates made additional contributions to the WHO after Trump declared that the United States had left WHO (Norbrook 2020).

For instance, China has provided USD 50 million in assistance to the WHO, shared information on the pandemic situation and virus research with the WHO, and accepted the WHO's visit to investigate the source of the pandemic (Shih 2020). Germany, France, the United Kingdom, and other EU countries have supported the WHO. Given the pandemic situation. United States does not continue to help global health effectively. Richard Horton, editor in chief of the Lancet, called the withdrawal of the United States from the WHO an atrocity against humanity (Knight 2020). These individuals are globalists upholding the purpose of international organizations and humanitarianism.

\subsection{Identification of Disease Source}

The accurate identification of a disease source must be based on scientific research. Under the objective reality that the pandemic is spreading worldwide, and the source of the disease has been found in many places, globalists have been avoiding regional stigmatization and discriminatory naming and promoting neutral medical science nomenclature; nationalists assume that the virus has been purposefully and deliberately transmitted by a specific country, without scientific evidence.

Nationalists are social groups with a strong ideology and value orientation; they are more likely to show extreme nationalism tendency. However, globalists are more objective and scientific than social groups are and advocate internationalization and global subjectivity in the study of scientific issues.

Trump and Pompeo stigmatized the source of the disease as the "Wuhan virus" and "Chinese virus" (Mangan 2020), while scientists, research institutions, and medical staff have conducted continuous objective scientific research. Some individuals in the United States even think that the coronavirus is a human-made biological and chemical weapon because the current pandemic situation is raging in the US, the European Union, and other parts of the world. China controlled the pandemic within two months. Peter Navarro, director of the White House National Trade Council, claimed that China deliberately created and sent individuals to spread the virus to harm the United States (Somodevilla 2020). In his National Day speech on July 4, Trump reiterated that the US economy had been severely damaged by the "Chinese plague" (Sergers 2020).

Although the surveillance of the virus strain at the time of the outbreak in Beijing in June reported that the virus's sequence was similar to that of early strains in the European Union, China neither considered it imported nor stigmatized the European Union. As early as April 2020, based on the research on the gene sequence of the virus by scientists from different countries, the WHO repeatedly reiterated that the virus was not made artificially but originated from nature (Sepeda-Miller 2020). However, the US side refused this explanation on the grounds of national security.

Globalists hold an objective and cooperative attitude toward the source of the virus. Notably, the COVID-19 pandemic is a global public health crisis. Medical professionals, scientists, and intellectuals cooperate in determining the source of the 
virus, without political prejudice. Chinese expert Nanshan Zhong pointed out: the pandemic occurred in Wuhan, but that does not mean that Wuhan is the source (Guo 2020).

\subsection{Vaccine Research}

Attitudes toward the task of vaccine research may differ among nationalists and globalists. Nationalists hope to monopolize the whole process from virus acquisition to vaccine research and development, production, acquisition, and sales, prioritizing their citizens and safeguarding their health and safety interests; globalists claim that vaccines are global public welfare products.

The Trump administration "decoupled" the United States from China, abandoning the possibility of cooperative research and development with China and thus interrupting the funding of the new coronavirus research project between China and the United States; moreover, they attempted to monopolize the right to use vaccines. Gustav Pena, the administration's appointed vaccine research and development leader, also ruled out the possibility of developing cooperation with China. The US National Institutes of Health released a project to develop therapeutic regimens and vaccines, with 18 pharmaceutical companies from the United States, Japan, Germany, the United Kingdom, France, and Switzerland, excluding China. The WHO has been improving its genome-wide research program. The United States has been developing vaccines separately and may have had an earlier start than the WHO. Additionally, the United States has obtained virus strains from China but has not provided the same to China and the WHO. Furthermore, regarding the aforementioned suspended funding, 77 Nobel laureates criticized this policy as politicizing science (Lawder 2020). The Guardian reported that Paul Hudson, executive director of the Sanofi group in France, claimed that the vaccine developed by his company would be distributed to the United States first because they have been providing most of the funds for the research. In the same month, the US government claimed that China, also at the forefront of vaccine research and development, had stolen US vaccine research and development achievements through hacking (Blamont and Erman 2020).

By contrast, the globalists hold a more objective attitude toward scientific research on the virus. The EU countries have emphasized international cooperation in vaccine research and development. China has participated in disease control with the G20 and African countries (Global Times 2020). Additionally, WHO DirectorGeneral Tedros Ghebreyesus stated that the vaccine should be considered a global health public good (Gretler 2020). In January 2020, US Health and Human Services Secretary, Alex Azar, said: China's release of gene sequencing results is remarkable. The team of the US Centers for Disease Control and Prevention developed diagnostic tools within one week, and the National Institute of Allergy and Infectious Diseases seeks to develop candidate vaccines in a few weeks (Karlin-Smith 2020). The European Union launched the coronavirus global response on May 4, with a plan to raise EUR 7.5 billion for more effective research and development. As stated by European Commission President von der Leyen, the price of vaccines should 
be affordable to everyone worldwide (European Commission 2020). However, the United States did not participate. Although China also did not participate, it actively participated in the disease control cooperation between the G20 and the African continent (Global Times 2020).

\subsection{International Cooperation}

International cooperation in this study primarily refers to the moral and material support and assistance between countries. Because of the pandemic, countries have supported and assisted each other. However, nationalists follow the principle of national interests first and rarely provide foreign aid; thus, many countries are unable to implement foreign and international assistance; globalists provide multidimensional international assistance within their ability.

Globalists have been generous in their foreign aid during the outbreak. For instance, China has helped Italy, which had high infection and death rates in the early stage of the first wave of the pandemic in the European Union (Barigazzi 2020). China also held an international Sharing Conference on disease prevention and control to share scientific data, technological achievements, and prevention and control strategies with the global scientific and technological community (Global Times 2020).

By contrast, the US State Department called on other countries not to hire Cuban medical teams because that plan would be "insulting" (Rodríguez 2020). This statement conveyed ideological bias, national antagonism, and racial discrimination. Additionally, some media and experts in the European Union and the United States accused China of using ideological output and claimed that China's aid materials had problems with quality and utility. After conducting quality control in China, it was accused of monopolizing and blocking anti-pandemic materials. Since March, the Brookings Institution, Forbes, Voice of America, and other media have provoked "mask diplomacy," accusing China of publicizing its institutional advantages by donating masks and linking China's aid behavior with geopolitical intentions (Ma 2020). The French newspaper Le Monde described "mask diplomacy" as "generous politics," seizing the danger of others to compete for geopolitical influence (Frachon 2020). Przychodniak(2020), of the Polish Institute of International Affairs, said that the central and eastern countries in the European Union that received China's assistance were grateful for the help but felt uneasy about the political and economic motives of the aid. J. Borrell, head of the European Union's external action agency, warned EU member states about China's aid: be aware of geopolitical factors (Guillot 2020).

\subsection{Social Reaction}

Social reactions reflect the different values and social actions of ordinary individuals during the pandemic. It is not only a social expression of social structures but also a type of moral belief feedback of social culture in different countries. Different cultural values and action strategies in different fields can be shown based on 
individuals' different insights into globalization, the national consciousness, the national concept, and social responsibility. The social actions of nationalists are parochial, radical, and unilateral. Additionally, globalists' social actions are for public welfare and public health interests.

At the social level, nationalists and globalists respond differently. This difference is primarily reflected in the various social actions of the social elites and the rest of the public. For instance, Bill Gates strongly supported the pandemic control work of the WHO and China, but this caused dissatisfaction among US grassroots groups (Wakefield 2020). Jack Ma donated kits and masks to the United States, but some Chinese netizens criticized him for that (Savov 2020). However, Elon Musk, an entrepreneur, was indifferent to the pandemic and forced his workers to return to work (Tom 2020).

Some individuals in the United States, Brazil, the, and other countries have rejected living in isolation to control the virus and, by contrast, support an instant economic restart. Some grassroots groups in the United States, Brazil, the United Kingdom, and Italy in the early stage of the pandemic, such as supporters of Trump and his Republican Party, have refused to wear masks because the influence of leadership and the media and are opposed to the closure of cities to control the virus. They firmly advocate individual freedom and think China is responsible for the spread of the pandemic in their country. Notably, the blind self-confidence and support for a restart in the mentioned countries are primarily from the lower-educated blue-collar middle-lower class individuals who are forced to make a living or are willingly misled by politicians.

However, individuals in China, Japan, South Korea, Germany, and other countries have recognized reality and implemented strict control measures, thereby rapidly controlling their domestic pandemic situations in a short period after the outbreak of disease, compared to countries with passive attitudes. White-collar workers have demonstrated collective and social self-discipline. By contrast, although the United States, Brazil, and other countries continue to manage serious pandemic situations, they have become a burden to international pandemic control and world economic recovery.

\section{The Social Group Distinction Between Nationalists and Globalists}

The social group distinction between nationalists and globalists has six characteristics.

First, obvious differences are identified in social class and social status between the two opposite social groups. On the whole, many nationalists are political leaders, who are heads of government, right-wing conservatives, and others who exhibit higher power status and represent the interests of the nation-state. They have the support of grassroots individuals and are sheltered by them. Globalists are primarily international and regional organizations leaders, intellectuals, philanthropists, and others who believe in multilateralism and liberalism, as well as those in the rational upper and middle classes. 
Second, the social distinction between nationalists and globalists is the differences in their respective values and action strategies, and the cultural gap between moral ethics and individual personality beliefs, instead of social distinction in the sense of conventional structure (e.g., spatial isolation or intergenerational distinction). In numerous fields, there are deep-rooted institutional barriers (e.g., ideologies, political systems, and ethnic differences). Each group conducts its social action strategies in different fields.

Third, different from the direct contact relationship and even mutual flow between other opposing social groups, the conflict between nationalists and globalists is gradually intensifying and will be difficult to ease in a short time or during the pandemic.

Fourth, there will be social integration and isolation between the two sides at the same time. In other words, the social group component of nationalists and globalists is diversified and complicated. During the pandemic, their respective camps will be split and reorganized continuously. Individuals exhibiting different political positions, ideologies, knowledge structures, social statuses, and economic interests will enter or leave the two groups for a long or short period.

Fifth, because it is difficult for the two sides to have direct conflicts and to manage the crisis together, the opposition of values between the two sides is relative, instrumental, and even interchangeable. For instance, nationalists show their powers (e.g., chauvinism, hegemonic consciousness, and racism toward hostile countries) but may be global and provide humanitarian aid to allies. Furthermore, nationalism and globalism are two sides of the same coin.

Sixth, during parallel development, the two self-test their legitimacy and rationality through an indirect game comparison of each other and finally determine their correctness and historical status. The final convergence of the two is not excluded. Therefore, a prediction is that if the nationalist countries with serious pandemic situations finally control the disease while recovering their economy, their nationalism will be rampant; if not, globalism will rise in these countries.

Based on this analysis, from the perspective of institutional and cultural origins, nationalists pursue jungle law, individualism, and social Darwinism under contemporary neoliberal capitalism; globalists uphold the humanitarianism and collectivism guided by social democracy and human well-being. Obviously, under the pandemic, the leaders of the United States, Brazil, and the United Kingdom who represent nationalism are conservatives having faith in free capitalism. The biggest value orientation of neoliberal capitalism refers to the identification with the social Darwinism of freemarket competition and the determinization of individuals. The leaders of China and Germany, which represent globalism, uphold social democracy and collectivism and emphasize the protection of citizens' social welfare.

With the continuous divergence of social groups in terms of the disease, the two sides are still fighting for the commanding heights of ethics and morality, which will profoundly impact the globalization of the world's national relations. 


\section{Impact on Globalization of Nationalists and Globalists in the Future}

After the COVID-19 pandemic, the globalization mode will be significantly changed, but globalization still has great vitality in the contemporary era. As revealed from this pandemic, globalism and international corporation have effectively controlled the global public health crisis and is a powerful means to solve international issues. The isolationism of extreme nationalists will not only fail to solve the global public health crisis but also cause extreme harm in nation-states.

The COVID-19 pandemic response, a global public health crisis, shows the necessary of the unity and cooperation of all countries. The external blockades and inaction to mandate public health policies at the beginning of the pandemic proved significantly harmful, causing millions of unnecessary infections and at least hundreds of thousands of unnecessary deaths. In the early phase of the pandemic, foreign aid from some countries effectively alleviated speed of the spread of coronavirus in the international community, gaining valuable time for the disease response in those countries. In addition to the public health crisis, climate change, refugee crises, and other issues are also expected to be solved by the unity and cooperation of all nations; if nation-states fail to recognize this, a global crisis similar to the COVID-19 pandemic will be inevitable.

Globalization had undergone many shocks before this pandemic, and it should be urgently reinvigorated. Especially because of the actions of the Trump administration on behalf of the United States, the long-time leader of globalization, globalization is experiencing great instability. To further its "America first" agenda, supported by conservative voters, the Trump administration has been withdrawing from the international cooperation system, triggering the supply crisis of international public goods. During this pandemic, the US government's withdrawal from the WHO once again shows the profound threat of globalization. In this scenario, the European Union, Japan, and the developing economies (e.g., China) are required to immediately resolve the international public goods crisis attributed to the isolationist foreign policy of the United States, for their national interests and for that of mankind.

During the pandemic, the shrinking of international trade and the reduction of individuals' mobility have suggested the rise of nationalism; it is therefore predicted that nationalism will rise rapidly in various nations for a certain period. The social discontent caused by the economic and social crises caused by the pandemic and the response to it will promote nationalism within the nationstates. To a certain extent, the development of nationalism facilitates contemporary nation-states, avoiding the internal division of the country, thereby aggravating more serious crises. Some globalists will temporarily turn to the nationalist side for their country's interest and may persist for a period. Accordingly, in a short period, the influence of nationalists worldwide will increase significantly compared with that of globalists.

The potential threat of extreme nationalism is notable. Historically, extreme nationalism has caused serious harm in the European Union, for example, World 
War II. The serious harm of extreme nationalism to international affairs and domestic affairs in countries (e.g., the United States) has been observed; thus, the development of extreme nationalism in the aforementioned countries should be reviewed. The vitality of globalism has been reflected in this pandemic and the globalization will continue to be vigorous for the well-being of mankind.

\section{Implications}

The pattern of international relations and the division of labor system of international cooperation under the current globalization will probably be seriously affected and even undergo profound changes after the pandemic. The interaction between the nationalists and globalists investigated in this study will affect the formation mode of the new international pattern.

In the globalization since the Cold War, the United States and the European Union countries have taken the top position in the international system and gained huge economic benefits through global cooperation. However, globalization has also had a negative impact on developed economies. Over the past few years, the terrorist threat and immigration problems caused by the cross-border movement of individuals have deeply troubled developed economies and led to the rise of conservative politics in these countries. The election of Trump in 2016 marks the strong counterattack of the nationalists in developed economies against globalization. Unfortunately, these anti-globalization measures indirectly exacerbated the global public health crisis of this pandemic.

Additionally, developing economies are beneficiaries of globalization but are disadvantaged in international economic cooperation. Over the past few years, China, India, Brazil, and other developing economies have become the fastest-growing countries worldwide in terms of economic growth and international investment. Compared with developed economies, developing economies are more vulnerable to the negative impact of globalization under the unfavorable conditions of economic and scientific levels. These results have led to an increase in populism in some countries. In several developing countries, the confluence of nationalists and populists has threatened the formulation of national policies. What can be observed is that the confluence of nationalists and populists in India, Brazil, and other countries has seriously jeopardized their public health policies and exacerbated this serious public health crisis.

This study attempts to expand world system theory to explore the changes in the international pattern in the new era of globalization. Through the modern world system theory of Immanuel Wallerstein (2004), which primarily discusses the division of labor in the worldwide economic system, the framework also has a strong explanatory power to explain the formation of nationalists and globalists and the division of social groups under the pandemic.

On the one hand, world system theory holds that the world's system determines nation-states' development. The rise and fall of the status of the nation-state in the world's system is primarily determined by the development cycle of the world's system. Every time the world economy moves up and down alternately, the marginal and 
semimarginal countries are likely to be promoted. Accordingly, the following is an explanation: marginal countries (e.g., Brazil) have attempted to use the pandemic crisis to enhance their national strength; the United States, as the central country, has suppressed the rising semimarginal countries such as China; and Germany, also among central countries, has attempted to maintain its status in the European Union and the world.

On the other hand, nation-states affect the world system. First, a nation-state is the antithesis of globalization. A nation-state acts as the carrier of the world system and the key element of the development of modern capitalism. After the emergence of capitalist relations of production, the dominant social forces have fully exploited the state to safeguard and develop their own interests. The monarchs of central countries have strengthened the state machinery by, for example, establishing bureaucracy (e.g., Trump's authority and right-wing cabinet), conducting unilateral policies (e.g., monopolizing vaccine development), constructing legitimacy (e.g., proposing "American first"), and promoting national integration (e.g., publicizing the personal interests of economic restart); thus, the state is allowed to make decisions regarding capital accumulation and value management. Second, state behavior affects the micro layout of the world system. The state does not refers to a simple political concept. Notably, the state machinery, political structure, and various political operation mechanisms are set based on specific economic, social, and political goals. Its basic function refers to promoting capital accumulation and affecting income distribution by intervening in market operation. In this study, economic prosperity, social stability, and high employment rates can be maintained by not following scientific advice during the pandemic and promoting economic restart before control measures have been effective; ultimately, the world will observe who is re-elected and if the interests of the Republican Party (in the United States) and large enterprise groups can be maintained. Accordingly, the state and its "social elites" and conservatives are participants, as well as the biggest nationalists and ultimate successors of vested interests. Furthermore, globalists seem to place more emphasis on the well-being of all mankind than on national interests.

Author contributions Both the authors contribute to the work of conception and research design. He is mainly responsible for the main framework of this article, Comparison between Nationalists and Globalists, The Social Group distinction between Nationalists and Globalists, and Implications. Chen is mainly responsible for Literature Review, Impact on Globalization of Nationalists and Globalists in the Future and general revising of the article. Both the authors read and approved the final manuscript.

Availability of data and materials All the materials can be found from published journals, newspapers and online websites.

\section{References}

Audi, Robert. 2009. Nationalism, patriotism, and cosmopolitanism in an age of globalization. The Journal of Ethics 13: 365-381.

Barigazzi, Jacopo. 2020. Italy's foreign minister hails Chinese coronavirus aid. Politico. https://www. politico.eu/article/italys-foreign-minister-hails-chinese-caronavirus-aid/. Accessed 15 July 2020.

BBC. 2020a. Coronavirus: Trump stands by China lab origin theory for virus. BBC. https://www.bbc. com/news/world-us-canada-52496098. Accessed 15 July 2020. 
BBC. 2020b. Russia holds World War Two victory parade in coronavirus shadow. BBC. https://www. bbc.com/news/world-europe-53152725. Accessed 15 July 2020.

Blamont, Matthias and Michael Erman. 2020. Exclusive: Sanofi can produce millions of doses of potential coronavirus drug - CEO. The Guardian. https://www.theguardian.pe.ca/news/world /exclusive-sanofi-can-produce-millions-of-doses-of-potential-coronavirus-drug-ceo-433110/. Accessed 15 July 2020.

Bourdieu, Pierre. 1984. Distinction: a social critique of the judgement of taste. Cambridge: Harvard University Press.

Braddick, Imogen. 2020. White House claims US is 'a leader' in fight against coronavirus pandemic. Evening Standard. https://www.standard.co.uk/news/world/white-house-america-leader-coron avirus-fight-a4490596.html. Accessed 15 July 2020.

De Cleen, Benjamin. 2017. Populism and nationalism. In: The Oxford Handbook of Populism, edited by Kaltwasser, Cristóbal R et al.: 342-362.

European Commission. 2020. Coronavirus Global Response: $€ 7.4$ billion raised for universal access to vaccines. https://ec.europa.eu/commission/presscorner/detail/en/ip_20_797. Accessed 15 July 2020.

Frachon, Alain. Dissecting China's Failed Experiment at Face Mask Diplomacy. Worldcrunch. https ://worldcrunch.com/coronavirus/dissecting-china39s-failed-experiment-at-face-mask-diplomacy. Accessed 15 July 2020.

Global Times, 2020. China-Africa friendship solid. https://www.globaltimes.cn/content/11919 88.shtml. Global Times. Accessed 15 July 2020.

Goodman, James. 2002. Nationalism and globalism: social movement responses. The International Scope 4: 1-17.

Greenfeld, Liah. 2011. The globalization of nationalism and the future of the nation-state. International Journal of Politics, Culture, and Society 24: 5-9.

Gretler, Corinne. 2020. Xi Vows China Will Share Vaccine and Gives WHO Full Backing. Bloomberg. https://www.bloomberg.com/news/articles/2020-05-18/china-s-virus-vaccine-will-be-globa 1-public-good-xi-says. Accessed 15 July 2020.

Guillot, Louise. 2020. Europe has been 'naive' about China, says Josep Borrell. Politico. https://www. politico.eu/article/europe-has-been-naive-about-china-josep-borrell/. Accessed 15 July 2020.

Hutchinson, John. 2003. Nationalism, globalism, and the conflict of civilizations. In Nationalism and its Futures, ed. Umut Özkirimli, 71-92. New York: Palgrave Macmillan.

Johns Hopkins University. 2020. COVID-19 Map. https://coronavirus.jhu.edu/map.html. Accessed 15 July 2020.

Kacowicz, Arie M. 1999. Regionalization, globalization, and nationalism: convergent, divergent, or overlapping? Alternatives 24: 527-556.

Karlin-Smith, Sarah. 2020. U.S. officials praise Chinese transparency on virus-up to a point. Politico. https://www.politico.com/news/2020/01/29/officials-praise-china-transparency-virus-10892 6. Accessed 15 July 2020.

Knight, Sam. 2020. The lancet editor's wild ride through the coronavirus pandemic. The New Yorker. https://www.newyorker.com/news/letter-from-the-uk/the-lancet-editors-wild-ride-through-thecoronavirus-pandemic. Accessed 15 July 2020.

Lawder, David. 2020. Trump threat to 'decouple' U.S. and China hits trade, investment reality. Reuters. https://www.reuters.com/article/us-usa-trade-china-analysis/trump-threat-to-decouple-u-sand-china-hits-trade-investment-reality-idUSKBN23U2WU. Accessed 15 July 2020.

LeBlanc, Paul. 2020. Trump to hold campaign rally in New Hampshire on Saturday. CNN. https:// edition.cnn.com/2020/07/05/politics/trump-campaign-rally-new-hampshire-coronavirus/index .html. Accessed 15 July 2020.

Lynch, David J and Emily Rauhala. 2020. Trump says U.S. to withdraw from World Health Organization and announces new broadsides against Beijing. The Washington Post. https://www.washi ngtonpost.com/business/2020/05/29/trump-china-hong-kong-who/. Accessed 15 July 2020.

$\mathrm{Ma}$, Alexandra. 2020. China is attempting to win political points from the coronavirus with 'mask diplomacy'—but it mostly isn't working. Business Insider. https:/www.businessinsider.com/ analysis-china-coronavirus-political-points-mostly-not-working-2020-4. Accessed 15 July 2020.

Malesevic, Sinisa. 2002. Globalism and nationalism: which one is bad? In Development and culture, ed. Deborah Eade, 38-44. Oxford: Oxfam. 
Mangan, Dan. 2020. Trump defends calling coronavirus 'Chinese virus' - it's not racist at all'. CNBC. https://www.cnbc.com/2020/03/18/coronavirus-criticism-trump-defends-saying-chinesevirus.html. Accessed 15 July 2020.

Mason, Jeff and Steve Holland. 2020. Trump unveils three-stage process for states to end coronavirus shutdown. Reuters. https://www.reuters.com/article/us-health-coronavirus-usa-guidelines/ trump-unveils-three-stage-process-for-states-to-end-coronavirus-shutdown-idUSKBN21Y31W. Accessed 15 July 2020.

Norbrook, Nicholas. 2020. Coronavirus: Bill Gates defends WHO from Trump, gives $\$ 11 \mathrm{~m}$. The Africa Report. https://www.theafricareport.com/26977/coronavirus-bill-gates-defends-whofrom-trump-gives-11m/. Accessed 15 July 2020.

Nyíri, Pál., J. Zhang, and M. Varrall. 2010. China's cosmopolitan nationalists: "Heroes" and "traitors" of the 2008 Olympics. The China Journal 63: 25-55.

Ohanyan, Anna. 2010. Nationalism in a globalizing context: governance focused intervention in the developing world. International Journal on World Peace 20: 29-53.

Przychodniak, Marcin. The EU Needs to Face China's Threat to Academic Freedom. China Observers. https://chinaobservers.eu/the-eu-needs-to-face-chinas-threat-to-academic-freedom/. Accessed 15 July 2020.

Rodríguez, Andrea. 2020. Cuban doctors battle COVID-19 around the globe, defying U.S. People's World. https://peoplesworld.org/article/cuban-doctors-battle-covid-19-around-the-globe-defyi ng-u-s/. Accessed 15 July 2020.

Rui, Guo. 2020. China has been transparent about Wuhan outbreak, virus expert Zhong Nanshan says. South China Morning Post. https://www.scmp.com/news/china/society/article/3047087/china -has-been-transparent-about-wuhan-outbreak-virus-expert. Accessed 15 July 2020.

Savov, Vlad. 2020. Jack Ma Sending Masks and Other Aid to Asia, Latin America. https://www. bloomberg.com/news/articles/2020-03-21/jack-ma-sending-1-8-million-masks-and-other-aid-toasia. Bloomberg. Accessed 15 July 2020.

Scotto, Thomas J., David Sanders, and Jason Reifler. 2018. The consequential nationalist-globalist policy divide in contemporary Britain: some initial analyses. Journal of Elections, Public Opinion and Parties 28: 38-58.

Sepeda-Miller, Kiannah. 2020. Fact-check: no, the novel coronavirus was not 'man-made'. Better Government Association. https://www.bettergov.org/news/fact-check-no-the-novel-coronaviru s-was-not-man-made/. Accessed 15 July 2020.

Sergers, Grace. 2020. Trump uses July 4 speech to defend "American heroes," attack China and the media. CBS News. https://www.cbsnews.com/news/watch-live-trump-to-deliver-4th-of-julyremarks-in-salute-to-america-event/. Accessed 15 July 2020.

Shih, Gerry. 2020. China pledges additional \$30 million funding for World Health Organization. The Washington Post. https://www.washingtonpost.com/world/asia_pacific/china-pledges-additional -30-million-funding-for-world-health-organization/2020/04/23/24f9b680-8539-11ea-81a3-9690c 9881111_story.html. Accessed 15 July 2020.

Steger, Manfred B. 2005. From market globalism to imperial globalism: ideology and American power after 9/11. Globalizations 2: 31-46.

Tom, Krisher. 2020. Elon Musk becomes champion of defying virus stay-home orders. ABC News. https://abcnews.go.com/Health/wireStory/tesla-ceo-elon-musk-restarted-california-facto ry-70624453. Accessed 15 July 2020.

Wakefield, Jane. 2020. How Bill Gates became the voodoo doll of Covid conspiracies. https://www.bbc. com/news/technology-52833706. BBC. Accessed 15 July 2020.

Wallerstein, Wallerstein. 2004. World system analysis: an introduction. Durham and London: Duke University Press.

Warf, Barney. 2012. Nationalism, cosmopolitanism, and geographical imaginations. Geographical Review 102: 271-292. 